\title{
Analysis of Streamflow Variability and Trends in the Meta River, Colombia
}

\author{
Marco Arrieta-Castro ${ }^{1}$, Adriana Donado-Rodríguez ${ }^{1}$, Guillermo J. Acuña $2,3, * \mathbb{D}$, \\ Fausto A. Canales ${ }^{1, *(D)}$, Ramesh S. V. Teegavarapu ${ }^{4}$ and Bartosz Kaźmierczak ${ }^{5}$ (D) \\ 1 Department of Civil and Environmental, Universidad de la Costa, Calle 58 \#55-66, \\ Barranquilla 080002, Atlántico, Colombia; marrieta12@hotmail.com (M.A.-C.); \\ niana97@hotmail.com (A.D.-R.) \\ 2 Department of Civil and Environmental Engineering, Instituto de Estudios Hidráulicos y Ambientales, \\ Universidad del Norte, Km.5 Vía Puerto Colombia, Barranquilla 081007, Colombia \\ 3 Programa de Ingeniería Ambiental, Universidad Sergio Arboleda, Escuela de Ciencias Exactas e \\ Ingeniería (ECEI), Calle 74 \#14-14, Bogotá D.C. 110221, Colombia \\ 4 Department of Civil, Environmental and Geomatics Engineering, Florida Atlantic University, \\ Boca Raton, FL 33431, USA; rteegava@fau.edu \\ 5 Department of Water Supply and Sewerage Systems, Faculty of Environmental Engineering, \\ Wroclaw University of Science and Technology, 50-370 Wroclaw, Poland; bartosz.kazmierczak@pwr.edu.pl \\ * Correspondence: fausto.canales.v@gmail.com (F.A.C.); guillermo.acunar@gmail.com (G.J.A.); \\ Tel.: +57-5-3362252 (F.A.C.)
}

Received: 29 March 2020; Accepted: 13 May 2020; Published: 20 May 2020

\begin{abstract}
The aim of this research is the detection and analysis of existing trends in the Meta River, Colombia, based on the streamflow records from seven gauging stations in its main course, for the period between June 1983 to July 2019. The Meta River is one of the principal branches of the Orinoco River, and it has a high environmental and economic value for this South American country. The methods employed for the trend detection and quantification were the Mann-Kendall (MK) test, the modified MK (MMK) test, and the Sen's slope (SS) estimator. Statistically significant trends (at a $95 \%$ level of confidence) were detected in more than $30 \%$ of the 105 evaluated datasets. The results from the MK test indicate the presence of statistically significant downward trends in the upstream stations and upward trends in the downstream stations, with the latter presenting steep positive slopes. The findings of this study are valuable assets for water resources management and sustainable planning in the Meta River Basin.
\end{abstract}

Keywords: streamflow trends; Mann-Kendall; modified Mann-Kendall; Sens's slope; Meta River

\section{Introduction}

The availability of water resources for agriculture, industry, and cities is fundamental to the welfare and sustainable development of modern human societies. Among these resources, rivers provide multiple benefits to humans, such as hydropower, waterways, recreation, and fishery. Besides their critical role in supporting biota and biodiversity, rivers provide essential ecosystem services like water purification and climate regulation [1]. Therefore, sustainable water resource management requires an adequate understanding of the behavior of hydrological regimes and processes occurring within the watershed that ultimately affect streamflow variability.

Detecting variability and trends in river streamflow time-series are vital for the appropriate management and planning of these water resources, as it diminishes the risks and detrimental effects associated with wrongfully assuming stationarity in hydrologic design. Some of these possible effects include: underestimating design flow rates for hydraulic structures, assigning water rights beyond 
the capacity of the river to supply them, and consequently, over-exploitation and insufficient water to sustain the ecosystems and other uses [2]. The importance of this research topic is supported by many recent papers on the subject, as hydrological trend assessments at different timescales (decadal, interannual, annual, seasonal, monthly) have been conducted for watersheds across the world [3-8], and they serve as evidence in the debate on climate change [9] and non-stationarity. It is worth mentioning the study by Su et al. [10] is of interest in the current context, where these authors evaluated data from the year 1948 to 2004 for detecting long-term streamflow trends in 916 large rivers all over the globe. Their findings indicate a higher tendency for decreases than for increases in streamflows in many regions of the world.

This paper employs a combination of nonparametric techniques for evaluating the existence of trends in streamflow time-series: the Mann-Kendall (MK) test, the modified Mann-Kendall (MMK) test, and the Sen's slope (SS) estimator. Succinctly, the MK and the MMK tests evaluate if a trend increases or decreases with time (monotonic change), examining whether to reject the null hypothesis (stationarity) and accept the alternative hypothesis (presence of monotonic trend) [11]. A simple definition of SS is the median of all the pairwise slope values of a set of observed data [12,13]. These two metrics have been utilized in several studies for hydrological trend assessments in the South American region over the last decade, and the following paragraphs summarize major insights gained from these studies.

Ndehedehe and Ferreira [14] used the MK test and SS for studying interannual changes in the Terrestrial Water Storage (TWS) (the sum of all surface and subsurface water) over twelve major watersheds in South America between 2002 and 2017, with mixed results in terms of significant, non-significant, upward and downward trends. Pellicciotti et al. [9] analyzed 30 years of data for detecting the presence of trends in precipitation and streamflow at annual, seasonal, and monthly timescales for the Aconcagua River watershed, a dry Andes basin in Central Chile. Their findings have identified a downward trend in the interannual average streamflow for the upper section of the river and strong effects caused by El Niño Southern Oscillation (ENSO) events. Vega-Jácome et al. [15] assessed hydrological changes caused by variations in the precipitation regime or by hydraulic structures in the Rimac River basin, the primary freshwater source of Lima. These authors found that regulation and diversion projects had a significant effect on increasing minimum flows and decreasing maximum flows but raised questions about ecosystem alteration issues. Morán-Tejeda et al. [16] used the MK test for detecting trends in precipitation and temperature in Ecuador, and their relation to the ENSO for the years between 1966 and 2011. They found signs of significant warming, but independent of the ENSO phenomenon.

López $[17,18]$ evaluated the presence of trends in discharges of several rivers of Argentinean watersheds. The first of these studies [17] appraised how different climate scenarios could affect the hydropower generation capacity in the Limay River basin, which in 2007 was the source of approximately $26 \%$ of the total generation in the country. In combination with two mathematical models, they used the MK test for evaluating the sensitivity of streamflow to climate change. In the second one [18], the authors performed a trend analysis on 21 hydrological variables recorded at seven gauging stations located in the Province of Mendoza, where they found significant trends in 19\% of the time-series.

Trend detection is a current topic in hydrological research in Brazilian watersheds. Several authors have employed the MK test for the analysis of streamflow and precipitation trends in human-populated basins [19-21], the evaluation of the impacts of land-cover and land-use changes on the hydrological regime [22], the estimation of resource availability for water distribution systems [23], and the assessment of surface water quality near urban centers [24], among other purposes.

Restrepo et al. [25] studied the monthly discharge data of ten Caribbean rivers. The authors' quantified the magnitude, long-term trends, and analyzed variability patterns of the discharges into the ocean. Their results showed significant upward trends in some of the rivers and the substantial influence of El Niño Southern Oscillation (ENSO) and Intertropical Convergence Zone (ITCZ) migration on fluvial 
discharge. In a follow-up study, Restrepo et al. [26] found the existence of a strong interrelation between long-term trends and hydrological periodicities. There were annual, interannual, and quasi-decadal periodicities, the latter matching with major ENSO oscillation of the inter-annual band, probably, the most prominent cause of hydrological variability of the rivers draining into the Caribbean Sea.

Restrepo and Escobar [27] examined the presence of trends in suspended sediment load (SSL) time-series in the Magdalena River basin. Their findings indicate that increasing trends in sediment loads correlate with the increases in forest clearance and land cover changes. Restrepo et al. [28] analyzed the several decades of hydrological series of water discharge and SSL in the Magdalena River, and how the interannual variability of these parameters is related to periods of extreme climatic events (ENSO and La Niña).

The paper by Ávila et al. [29] evaluated climate indices of rainfall data in the high basin of the Cauca River, aiming at identifying spatial and temporal precipitation trends, as well as the relation between historical floods and ENSO. Their results indicate a statistically significant correlation between sea surface temperature (SST) and indices of extreme precipitation. Their findings also suggest a lag time of 2-3 months between ENSO and SST, which is very important for forecasting floods and understanding rainfall events and climate variability in watersheds in the Colombian Andes. A similar study by Puertas-Orozco et al. [30] studied seasonal and monthly rainfall data to analyze variations in water availability due to climatic variability in gauging stations of the upper and middle Cauca River basin. Carmona and Poveda [31] assessed 157 hydrological stations (with at least 25 years of records) to identify the existence of long-term trends in minimum air temperature, monthly rainfall, and average river discharges. As a result, river discharge showed significant decreasing trends per year, while the minimum temperature exhibited increasing trends, suggesting signs of climate change and climate variability in this region of tropical South America.

The Meta River, in Colombia, is one of the principal branches of the Orinoco River. Besides its natural value, this river is pivotal to the Colombian development and economic growth because it connects several regions with high productive potential [32]. Therefore, improving navigability in the Meta River has become one of the main goals of the Colombian government over recent times [33]. The literature review shows that trend detection and analysis studies have not been conducted before for the streamflow in this river. Therefore, the objective of this paper focuses on identifying and analyzing trends in the Meta River streamflow, based on records from seven gauging stations on its main course, for the period 1983-2019. This type of study is relevant because a proper knowledge about the available streamflow and its associated water level allows adequate and safe planning of inland waterways and their structures [34].

\section{Materials and Methods}

\subsection{Case Study: Meta River}

The Meta River Basin, in Colombia, is home to more than half a million people. Meta River is one of the largest tributaries of the Orinoco River and has its source on the eastern side of the Andes, in the vicinity of the town of Guamal. According to field measurements conducted in 2013 by Universidad del Norte [35], the Meta River has an approximate length of $1002 \mathrm{~km}$, encompassing a watershed area estimated between 99,500 and 105,000 km $\mathrm{km}^{2}$ [32,36]. This river is the boundary between several Colombian Departments (the primary administrative divisions within the country), and it flows through Meta, Casanare, Arauca, and Vichada, reaching the frontier with Venezuela. The Meta River contributes around $10 \%$ of water and nearly $50 \%$ of the total sediment load to the Orinoco River [37]. Figure 1 presents the Meta River Watershed and the location of the seven gauging stations evaluated in this study.

The Meta River has a significant environmental value for the Colombian Plains region. More than 1500 fish species and several protected mammals species inhabit its watershed, and the wetland areas in this basin cover approximately $20,000 \mathrm{~km}^{2}$ [32,38]. It also has considerable strategic value as 
an inland waterway, and improving its navigability is one of the national policies for promoting the development and economic growth of this Colombian region [33].

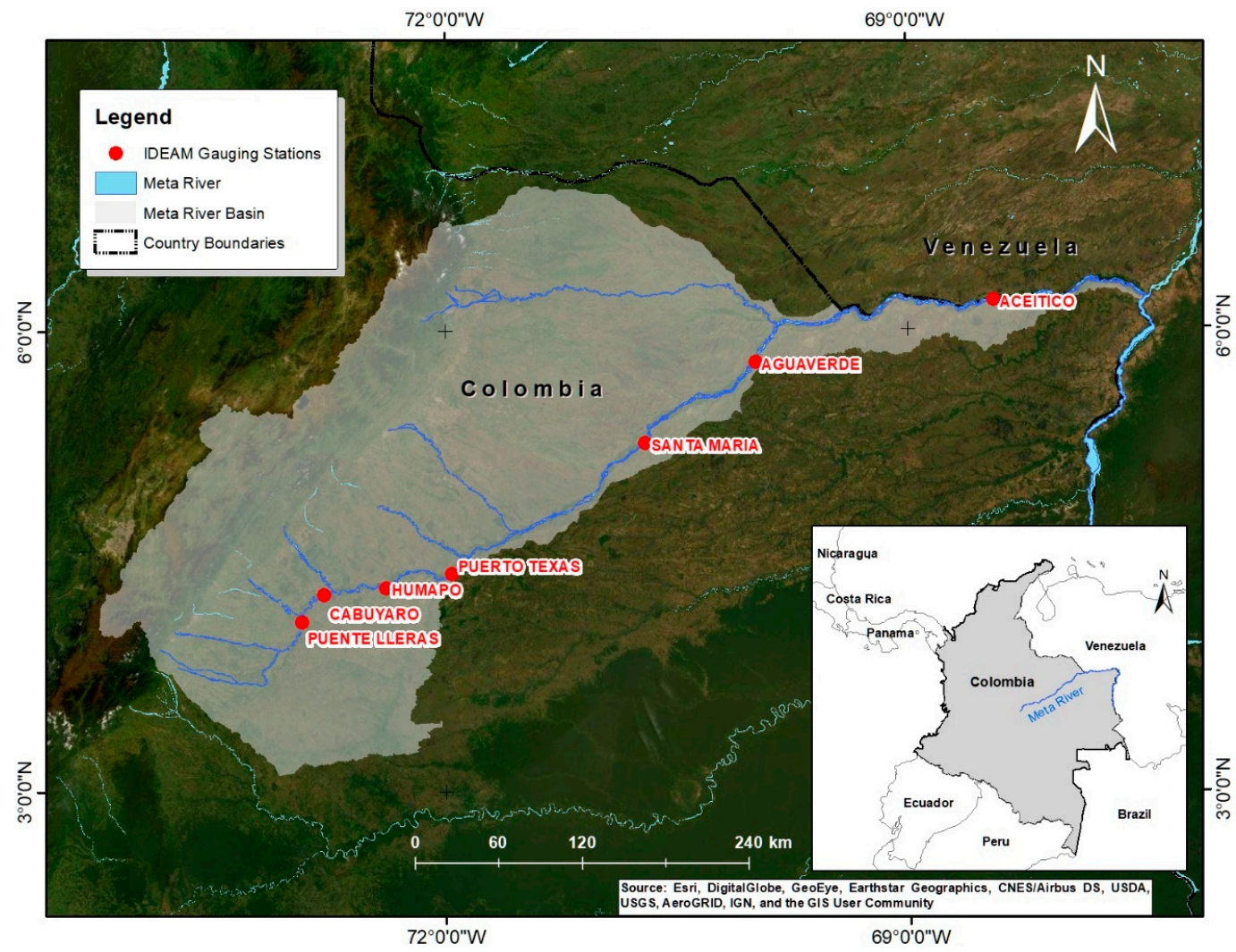

Figure 1. Location of the gauging stations along the Meta River.

\subsection{Gauging Stations and Data Preprocessing}

The analysis reported in this study uses a set of available streamflow time-series from seven gauging stations (four automatic and three conventional) in the Meta River watershed for evaluating the existence of trends. Each one of these time-series covers over 30 years of average daily records, and they are available from the IDEAM (Institute of Hydrology, Meteorology, and Environmental Studies) site [39]. Table 1 lists (upstream to downstream) the main features of these stations, including watershed areas for these stations, according to IDEAM (2010) [38]. Rating curve functions (RC) and the closest station method (CSM) were employed in this paper to fill the gaps in the time-series. The area in Table 1 corresponds to the watershed area above each gauging station.

Table 1. Details of the gauging stations in the Meta River assessed in this study.

\begin{tabular}{ccccccc}
\hline Site No. & Station Code & Station Name & Type & Location Coordinates & $\begin{array}{c}\text { Area } \\
\left(\mathbf{k m}^{2} \mathbf{)}\right.\end{array}$ & Records Available \\
\hline 1 & 35017020 & Puente Lleras & AUTO & $4^{\circ} 06^{\prime} 10.9^{\prime \prime},-72^{\circ} 56^{\prime} 11.0^{\prime \prime}$ & 8170 & $01 / 1977$ to $10 / 2019$ \\
2 & 35107030 & Cabuyaro & CONV & $4^{\circ} 16^{\prime} 51.6^{\prime \prime},-72^{\circ} 47^{\prime} 35.9^{\prime \prime}$ & 13,951 & $01 / 1977$ to $10 / 2019$ \\
3 & 35117010 & Humapo & AUTO & $4^{\circ} 19^{\prime} 40.0^{\prime \prime},-72^{\circ} 23^{\prime} 29.7^{\prime \prime}$ & 23,033 & $04 / 1978$ to $10 / 2019$ \\
4 & 35177020 & Puerto Texas & CONV & $4^{\circ} 25^{\prime} 06.2^{\prime \prime},-71^{\circ} 57^{\prime} 39.5^{\prime \prime}$ & 40,373 & $04 / 1978$ to10/2019 \\
5 & 35267030 & Santa María & CONV & $5^{\circ} 16^{\prime} 15.0^{\prime \prime},-70^{\circ} 42^{\prime} 20.1^{\prime \prime}$ & 67,325 & $02 / 1983$ to $08 / 2019$ \\
6 & 35267080 & Aguaverde & AUTO & $5^{\circ} 47^{\prime} 31.0^{\prime \prime},-69^{\circ} 59^{\prime} 16.4^{\prime \prime}$ & 76,137 & $06 / 1983$ to $08 / 2019$ \\
7 & 35257040 & Aceitico & CONV & $6^{\circ} 11^{\prime} 00.8^{\prime \prime},-68^{\circ} 26^{\prime} 29.3^{\prime \prime}$ & 104,135 & $02 / 1983$ to $08 / 2019$ \\
\hline
\end{tabular}

\subsection{Statistical Analysis of Trends}

The methodology adopted in this study is explained via a series of steps aimed at determining any existing trends in the streamflow data of seven gauging stations of the Meta River. This work 
assesses the existence of trends in the annual maximum, annual minimum, mean annual, and monthly mean flows. The MK and SS tests are nonparametric statistical methods used to evaluate trends. These metrics are commonly employed to assess temporal variations in hydro-meteorological variables, as they are two of the most robust methods for detecting and estimating the magnitude of trends [5]. The flowchart shown in Figure 2 describes the series of steps followed in this study.

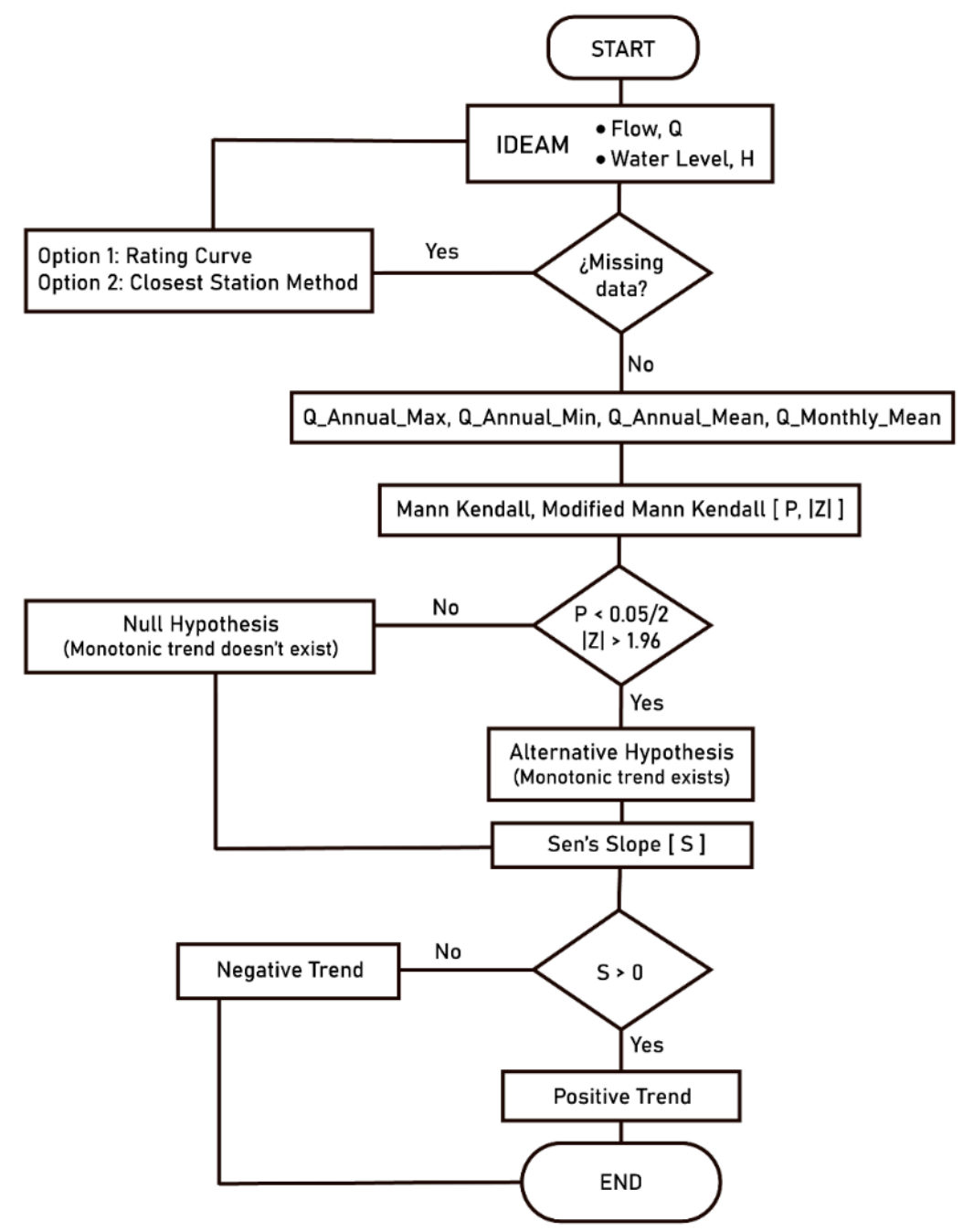

Figure 2. Flowchart describing a series of steps for trend analysis.

\subsubsection{MK Test}

Developed initially by Mann in 1945, and later modified by Kendall in 1975, the MK test for trend assessment is a widely used method for detecting monotonic trends in hydrological time-series [2]. Some of the Mann-Kendall's advantages is that it adapts to missing values and is minimally affected by atypical data [40]. The procedure requires comparing data pairs, meaning that each record gets compared to every other record in the time-series [4,41].

The absence of a trend is the null hypothesis of the MK test, and the alternative hypothesis postulates the existence of a monotonic trend in the time-series. It is possible to reject the null hypothesis only if $\mathrm{p}<\alpha$, at the test significance level $\alpha$ [2]. For this study, the adopted significance equals 0.05 , which, in a two-tailed test $(\alpha / 2)$, corresponds to $|Z|=1.96$ [5].

The MK test value is estimated as follows:

$$
S=\sum_{k=1}^{n-1} \sum_{j=k+1}^{n} \operatorname{sign}\left(X_{j}-X_{k}\right)
$$


where sign equals to:

$$
\operatorname{Sign}(x)=\left\{\begin{array}{c}
+1 \text { if }\left(X_{j}-X_{k}\right)>0 \\
0 \text { if }\left(X_{j}-X_{k}\right)=0 \\
-1 \text { if }\left(X_{j}-X_{k}\right)<0
\end{array} .\right.
$$

In Equation (2), the values $X_{j}$ and $X_{k}$ are measurements corresponding to a time $j$ and $k$, and $n$ is the number of events.

The following expression estimates the variance of $S$ :

$$
\operatorname{Var}(S)=\frac{n(n-1)(2 n+5)-\sum_{i=1}^{m} t_{i}\left(t_{i}-1\right)\left(2 t_{i}+5\right)}{18},
$$

where $n$ is the number of observations, $m$ is the number of data pairs in the series, and $t_{i}$ is the number of ties of the sample at the time $i[5,12]$.

The probability that associates $S$ with its variance is necessary to determine the significance of the trend, Z:

$$
\left\{\begin{array}{cc}
z=\frac{S-1}{\sqrt{\operatorname{Var}(S)}} & \text { if } S>0 \\
z=0 & \text { if } S=0 \\
z=\frac{S+1}{\sqrt{\operatorname{Var}(S)}} & \text { if } S<0
\end{array} .\right.
$$

\subsubsection{Modified Mann-Kendall (MMK) Test}

The MMK test, proposed by Hamed and Rao [42], is a better fit than the MK test for detecting trends in the presence of autocorrelation, which is a common feature noted in hydrological time-series. Applying the MK test to autocorrelated hydrological data could result in overestimating or underestimating actual trends [43]. In addition, if the data are independent, assuming autocorrelation may lead to failure in identifying trends. The MK and the MMK tests differ in the way the variance is calculated, as the variance is underestimated if data are correlated [44]. Therefore, for the MMK test:

$$
\operatorname{Var}(S)^{*}=\operatorname{Var}(S) \frac{n}{n^{*}}
$$

where $V(S)^{*}$ is the modified variance, and the correction factor $n / n^{*}$ is computed by:

$$
n / n^{*}=1+\frac{2}{n(n-1)(n-2)} \sum_{j=1}^{n-1}(n-k)(n-k-1)(n-k-2) r_{k}^{R}
$$

and $r_{k}^{R}$ is the lag- $k$ autocorrelation coefficient of the ranks of the data.

\subsubsection{Sen's Slope Estimation}

The Theil-Sen slope estimator, usually called SS, is a nonparametric metric that allows estimating the magnitude of change in the trends. As the MK test, SS is not affected by outliers and nonnormal distributions or being strict about homoscedasticity $[12,45]$. This magnitude is calculated by estimating the slopes of the lines $\left(Q_{i}\right)$ that connect the data pairs $(N)$ through the following equation:

$$
Q_{i}=\frac{Y_{j}-Y_{k}}{j-k} \text { for } i=1, \ldots, N,
$$

where $Y_{j}$ and $Y_{k}$ are values corresponding to periods $j$ and $k$, respectively. After calculating the slope for every data pair, the $Q$ values are arranged in ascending order, allowing to compute the median using the following expression. 


$$
\left\{\begin{array}{cc}
Q_{\text {med }}=Q_{|(N+1) / 2|} & \text { If } \mathrm{N} \text { is odd } \\
Q_{\text {med }}=\frac{Q_{|N / 2|+Q_{|(N+2) / 2|}}}{2} & \text { If } \mathrm{N} \text { is even }
\end{array} .\right.
$$

\section{Results}

\subsection{Trend Analysis Results for the Average Monthly Streamflow}

Preprocessing of the data and filling the gaps in the time-series preceded the analysis of the trends. The mean daily streamflow for the period 1977 to 2019 from seven gauging stations on the Meta River watershed ranged between $17 \mathrm{~m}^{3} / \mathrm{s}$ (minimum streamflow at Puente Lleras, the nearest station to the river source) and 17,000 $\mathrm{m}^{3} / \mathrm{s}$ (the maximum streamflow at Aceitico, the last station before discharging in the Orinoco River). The time-series between June 1983 and July 2019 is complete for all the stations assessed in this study. Consequently, this period is chosen for evaluating the existence of trends in the Meta River.

Figure 3 shows the average monthly streamflow for each one of the seven gauging stations under analysis, with the dark line representing the average and the blue and light blue shaded areas reflecting the range within one and two standard deviations. The hydrographs from the gauging stations exhibit a unimodal distribution within the year, with peak flow between June and July. Figure 3 also indicates that the dryer months (from January to March) have almost constant mean streamflows. Similar behavior is noted for the period between September and October, but it is more noticeable in the upstream stations (Puente Lleras and Cabuyaro).

A hypothesis test (e.g., Shapiro-Wilk (SW) [46] or Kolmogorov-Smirnov (KS) [12]) can be used to asses the normality of time-series to verify if a dataset follows a standard normal distribution, which is an essential underlying assumption of several statistical methods. If the data set fails to comply with the normal distribution assumption, this might indicate an inaccurate regression model, or the presence of influential outliers [47], with the latter being a common feature in hydrological time-series. Thus, the robustness of the MK test against atypical data highlights its adequacy and relevance for assessing the existence of trends in this type of time-series. The Shapiro-Wilk (SW) [46] and the Kolmogorov-Smirnov (KS) [12] tests were conducted for verifying normality of the annual maximum, annual minimum, annual average, and monthly mean flows at each gauging station. From the 105 datasets evaluated for trends, $23 \%$ of the datasets failed the normality tests, mostly the SW tests. The authors considered that if the time-series fails at least one of the two tests (SW or KS), the data do not follow a normal distribution. It is also worth mentioning that the Spearman's Rho is another test used extensively for trend detection, and it produces similar results to those provided by the MK test [48].

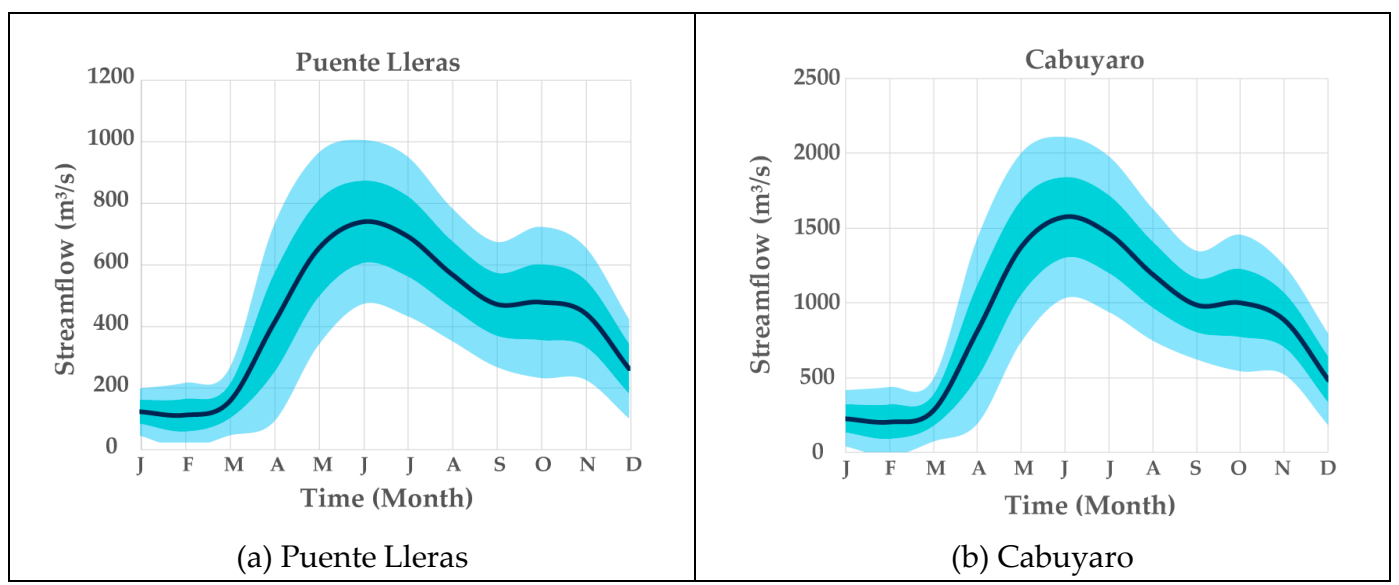

Figure 3. Cont. 


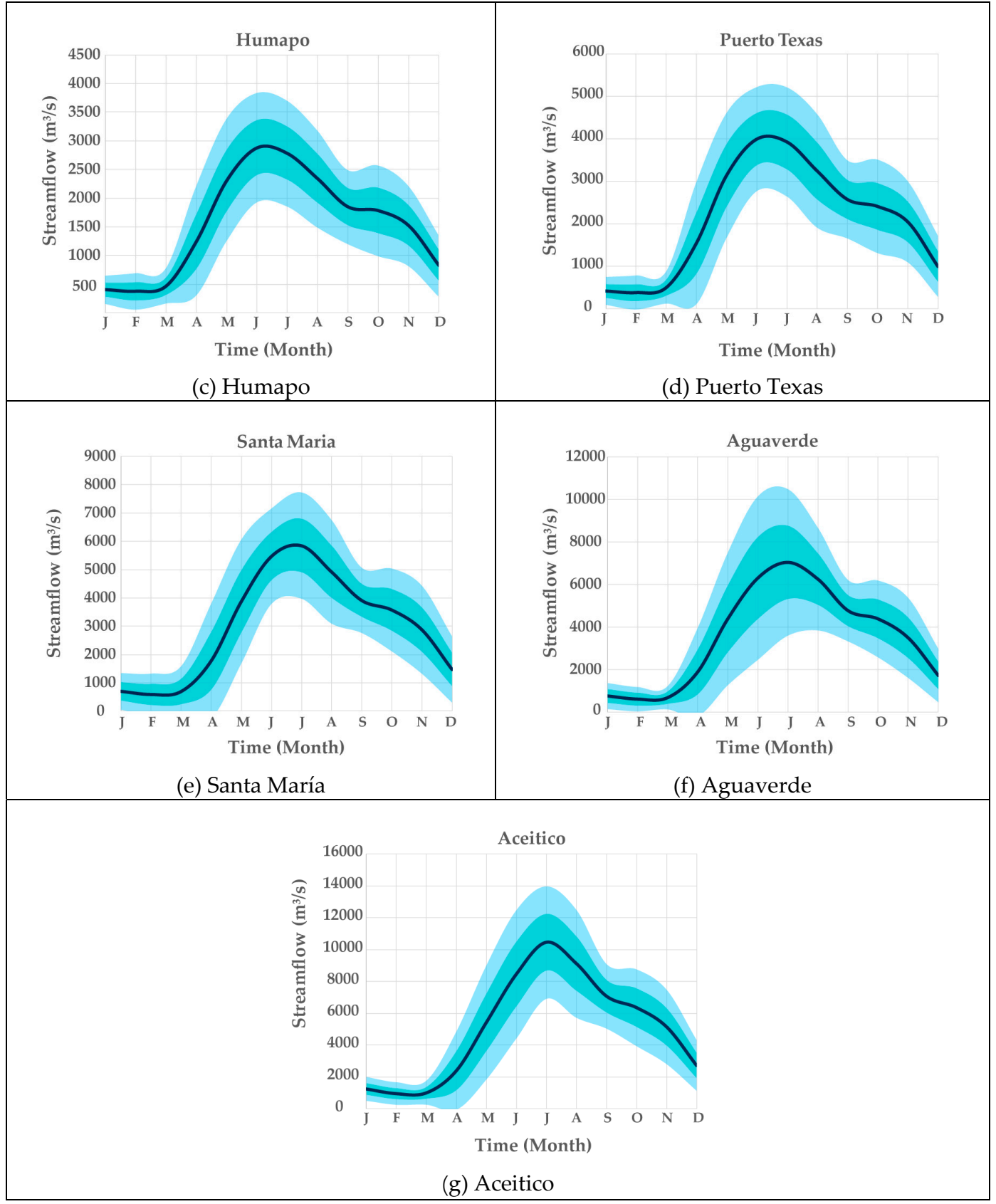

Figure 3. Average streamflow hydrographs for the seven gauging stations of the study.

Table 2 shows the results from the application of the MK and MMK tests and SS estimator to the monthly mean streamflow. For each month, the values presented in bold and italics indicate significant trends $(|Z|>1.96,5 \%$ significance level) in the average streamflow. April is the month with the highest number of significant trends, with six of the stations showing upward (positive) streamflow trends. This rank is followed by February, presenting downward (negative) streamflow trends in five gauging stations. For January, March, August, and December, none of the seven gauging stations exhibited any significant trends in the average streamflow.

In terms of the gauging stations, the results in Table 2 indicate that Santa Maria is the station with the highest number of months with significant trends (6), followed by Puerto Texas and Aguaverde with four months each. Humapo displays a stationary behavior on a monthly scale, exhibiting significant trends only in two months. 
Table 2. Summary of average monthly streamflow trend test using Mann-Kendall (MK) test, the modified MK (MMK) test, and the Sen's slope (SS) estimator in the Meta River.

\begin{tabular}{|c|c|c|c|c|c|c|c|c|c|c|c|c|}
\hline Test & Jan & Feb & Mar & Apr & May & Jun & Jul & Aug & Sep & Oct & Nov & Dec \\
\hline \multicolumn{13}{|c|}{ PUENTE LLERAS } \\
\hline Normality & YES & $\mathrm{NO}$ & YES & YES & YES & YES & YES & YES & YES & NO & YES & YES \\
\hline$M K Z_{S}$ & 0.68 & -0.72 & 0.31 & 2.22 & -0.37 & -1.69 & -2.11 & -1.40 & -2.11 & -2.47 & -0.12 & -0.04 \\
\hline$M M K Z_{S}$ & 0.68 & -0.72 & 0.31 & 5.25 & -0.37 & -1.91 & -2.55 & -1.40 & -2.42 & -2.47 & -0.12 & -0.04 \\
\hline $\mathrm{SS}\left(\mathrm{m}^{3} / \mathrm{s}\right)$ & 0.47 & -0.54 & 0.30 & 5.27 & -0.78 & -3.79 & -4.48 & -2.34 & -3.42 & -3.96 & -0.15 & -0.20 \\
\hline \multicolumn{13}{|c|}{ CABUYARO } \\
\hline Normality & $\mathrm{NO}$ & NO & YES & YES & YES & YES & YES & YES & YES & YES & YES & YES \\
\hline$M K Z_{S}$ & -1.29 & -2.33 & -1.38 & 2.41 & 1.65 & 0.64 & -0.46 & -1.57 & -1.02 & -1.02 & 1.35 & -0.23 \\
\hline MMK $Z_{S}$ & -1.63 & -2.33 & -1.38 & 3.89 & 1.65 & 0.82 & -0.46 & -1.57 & -1.02 & -1.02 & 1.35 & -0.23 \\
\hline $\mathrm{SS}\left(\mathrm{m}^{3} / \mathrm{s}\right)$ & -1.89 & -3.71 & -2.20 & 11.96 & 9.51 & 3.70 & -2.47 & -6.31 & -3.69 & -4.01 & 4.16 & -0.56 \\
\hline \multicolumn{13}{|c|}{ HUMAPO } \\
\hline Normality & YES & $\mathrm{NO}$ & YES & YES & YES & YES & YES & YES & YES & YES & YES & YES \\
\hline $\mathrm{MK} Z_{\mathrm{S}}$ & -1.08 & -2.68 & -1.62 & 1.78 & 2.14 & 2.42 & 1.32 & -0.31 & -1.35 & -0.86 & 0.99 & -0.59 \\
\hline$M M K Z_{S}$ & -1.08 & -3.73 & -1.62 & 1.78 & 2.14 & 3.07 & 1.16 & -0.42 & -1.35 & -0.86 & 1.45 & -0.59 \\
\hline $\mathrm{SS}\left(\mathrm{m}^{3} / \mathrm{s}\right)$ & -2.45 & -5.18 & -4.65 & 15.62 & 20.18 & 17.53 & 9.86 & -2.60 & -7.78 & -6.86 & 4.53 & -2.21 \\
\hline \multicolumn{13}{|c|}{ PUERTO TEXAS } \\
\hline Normality & YES & NO & YES & NO & YES & YES & YES & YES & YES & YES & YES & YES \\
\hline$M K Z_{S}$ & -1.89 & -3.26 & -1.81 & 2.00 & 1.78 & 1.32 & 0.85 & -0.29 & -2.00 & -1.21 & 1.08 & -0.23 \\
\hline MMK $Z_{S}$ & -1.89 & -4.42 & -1.81 & 2.00 & 1.78 & 1.32 & 1.01 & -0.38 & -2.27 & -1.21 & 1.32 & -0.19 \\
\hline $\mathrm{SS}\left(\mathrm{m}^{3} / \mathrm{s}\right)$ & -5.94 & -8.76 & -5.76 & 20.69 & 27.00 & 11.91 & 8.72 & -4.66 & -14.40 & -13.11 & 7.26 & -1.09 \\
\hline \multicolumn{13}{|c|}{ SANTA MARIA } \\
\hline Normality & YES & YES & YES & NO & YES & YES & YES & YES & YES & YES & NO & $\mathrm{NO}$ \\
\hline$M K Z_{S}$ & -0.31 & -2.79 & -1.51 & 2.36 & 2.82 & 2.55 & 1.19 & 0.67 & 0.56 & 0.07 & 2.25 & 0.94 \\
\hline MMK $Z_{S}$ & -0.36 & -3.66 & -1.51 & 2.36 & 3.06 & 3.44 & 1.86 & 0.67 & 0.73 & 0.07 & 2.08 & 1.02 \\
\hline $\mathrm{SS}\left(\mathrm{m}^{3} / \mathrm{s}\right)$ & -1.27 & -8.41 & -4.74 & 27.24 & 52.47 & 32.14 & 16.43 & 11.28 & 3.41 & 1.11 & 21.13 & 6.97 \\
\hline \multicolumn{13}{|c|}{ AGUAVERDE } \\
\hline Normality & YES & YES & YES & $\mathrm{NO}$ & NO & YES & YES & YES & YES & YES & $\mathrm{NO}$ & YES \\
\hline$M K Z_{S}$ & -0.42 & -2.78 & -1.57 & 2.00 & 2.82 & 2.81 & 2.63 & 1.02 & 0.01 & -0.10 & 1.40 & 0.12 \\
\hline MMK $Z_{S}$ & -0.42 & -13.88 & -1.57 & 2.00 & 4.37 & 6.81 & 4.05 & 1.02 & 0.01 & -0.10 & 2.14 & 0.10 \\
\hline $\mathrm{SS}\left(\mathrm{m}^{3} / \mathrm{s}\right)$ & -1.63 & -10.19 & -6.44 & 29.89 & 66.88 & 60.55 & 49.64 & 19.88 & -0.04 & -2.47 & 17.51 & 1.51 \\
\hline \multicolumn{13}{|c|}{ ACEITICO } \\
\hline Normality & YES & YES & YES & NO & YES & YES & YES & $\mathrm{NO}$ & YES & YES & NO & YES \\
\hline $\mathrm{MK} \mathrm{Z}_{\mathrm{S}}$ & 0.07 & -1.29 & -1.43 & 2.30 & 2.30 & 1.79 & 3.02 & 1.19 & -0.04 & 0.10 & 1.46 & 0.78 \\
\hline $\mathrm{MMK}_{\mathrm{S}}$ & 0.07 & -1.29 & -1.43 & 2.30 & 3.62 & 3.70 & 2.47 & 1.19 & -0.04 & 0.10 & 2.41 & 1.00 \\
\hline $\mathrm{SS}\left(\mathrm{m}^{3} / \mathrm{s}\right)$ & 1.05 & -7.43 & -9.02 & 36.95 & 68.33 & 67.31 & 87.42 & 34.36 & -0.97 & 1.92 & 24.06 & 8.96 \\
\hline
\end{tabular}

MK $Z_{\mathrm{s}}: \mathrm{Z}$ value for the MK test; $M M K Z_{\mathrm{s}}: \mathrm{Z}$ value for the MMK test; values in bold and italics indicate significant trends detected $(p \leq 0.05,|Z| \geq 1.96)$.

\subsection{Trend Analysis Results for the Maximum Annual Streamflow}

Table 3 summarizes the results from the application of the MK and MMK tests and SS estimator to the maximum annual streamflows. The results indicate that, at a $5 \%$ level of significance and for both MK and MMK tests, four stations present a significant trend for this feature: Puente Lleras, Humapo, Aguaverde, and Aceitico. The time-series of two of these stations do not follow a normal distribution, with additional tests indicating that Puente Lleras fits better to a log-normal distribution, and Cabuyaro to Weibull distribution function.

According to SS values, three of the four stations mentioned above exhibit a positive annual significant trend $(|Z|>1.96)$. Only the Puente Lleras station presented a negative trend and the lowest magnitude of change, while the Aceitico gauging station showed an opposite behavior.

Table 3. Summary of annual maximum streamflow trend test using MK, MMK, and SS in the Meta River.

\begin{tabular}{ccccccccc}
\hline No & Station & Mean $\left(\mathbf{m}^{3} / \mathbf{s}\right)$ & Std.Dev $\left(\mathbf{m}^{3} / \mathbf{s}\right)$ & Normal Dist. & MK $\mathbf{Z}_{\mathbf{S}}$ & MMK Z & SS $\left(\mathbf{m}^{3} / \mathbf{s}\right)$ & AC \\
\hline 1 & Puente Lleras & 1019.81 & 189.18 & NO & $-\mathbf{2 . 0 9}$ & $-\mathbf{1 . 9 8}$ & -5.59 & NO \\
2 & Cabuyaro & 2282.23 & 249.88 & NO & -0.33 & -0.48 & -1.66 & NO \\
3 & Humapo & 3775.44 & 471.11 & YES & 2.92 & 3.42 & 21.91 & YES \\
4 & Puerto Texas & 5308.08 & 642.27 & YES & 1.37 & 1.48 & 17.34 & NO \\
5 & Santa Maria & 6995.69 & 861.26 & YES & 1.02 & 1.02 & 14.15 \\
6 & Aguaverde & 8765.48 & 1202.21 & NES & $\mathbf{3 . 1 0}$ & $\mathbf{3 . 1 0}$ & 53.15 \\
7 & Aceitico & 12163.66 & 2090.51 & YES & $\mathbf{3 . 5 2}$ & $\mathbf{3 . 0 0}$ & 115.74 & YES
\end{tabular}

MK $Z_{S}: Z$ value for the MK test; $M M K Z_{S}: Z$ value for the MMK test; values in bold and italics indicate significant trends detected $(p \leq 0.05,|Z| \geq 1.96)$; AC: Autocorrelation. 


\subsection{Trend Analysis Results for the Minimum Annual Streamflow}

Results from the trend analysis for the minimum annual streamflow provided in Table 4 indicate that five of the stations present a significant trend at a 95\% confidence level for this feature: Cabuyaro, Humapo, Puerto Texas, Santa María, and Aguaverde. The corresponding SS values indicate that all of these gauging stations present negative trends during this period (06/1983-07/2019). As shown in Table 4, none of the minimum annual streamflow time-series followed a normal distribution. Additional tests determined that the best fit for all these time-series is the Weibull distribution, except for Puerto Lleras, whose best fit is the Gamma distribution function.

Table 4. Summary of annual minimum streamflow trend test using MK and SS in the Meta River.

\begin{tabular}{ccccccccc}
\hline No & Station & Mean $\left(\mathbf{m}^{3} / \mathbf{s}\right)$ & Std.Dev $\left(\mathbf{m}^{3} / \mathbf{s}\right)$ & Normal Dist. & MK Z & MMK Z & SS $\left(\mathbf{m}^{3} / \mathbf{s}\right)$ & AC \\
\hline 1 & Puente Lleras & 53.103 & 32.934 & NO & -1.190 & -1.027 & -0.508 & YES \\
2 & Cabuyaro & 123.700 & 72.895 & NO & -3.335 & -3.230 & -2.811 & YES \\
3 & Humapo & 246.449 & 121.936 & NO & -3.047 & -3.855 & -4.175 & YES \\
4 & Puerto Texas & 347.865 & 162.288 & NO & -3.924 & -3.924 & -7.623 & YES \\
5 & Santa Maria & 420.324 & 177.590 & NO & -3.518 & -3.518 & -7.705 & NO \\
6 & Aguaverde & 486.232 & 235.372 & NO & -3.270 & -2.810 & -7.794 & NO \\
7 & Aceitico & 727.595 & 346.999 & NO & -1.648 & -1.216 & -8.270 & NO \\
\hline
\end{tabular}

MK ZS: $Z$ value for the MK test; MMK ZS: $Z$ value for the MMK test; values in bold and italics indicate significant trends detected ( $p \leq 0.05,|Z| \geq 1.96)$; AC: Autocorrelation.

\subsection{Trend Analysis Results for the Annual Average Streamflow}

Table 5 provides the trend analysis results for the annual average streamflows. Only Puente Lleras registered significant trends at a $95 \%$ confidence level, exhibiting a downward trend. Except for Santa Maria, the MK and the MMK tests for this feature produce the same $Z_{S}$ value. For the average discharge, and using the areas given at Table 1, the specific streamflow at Aceitico $\left(51.13 \mathrm{l} / \mathrm{s} / \mathrm{km}^{2}\right)$ is around $8 \%$ higher than the one observed at Puente Lleras $\left(47.41 / \mathrm{s} / \mathrm{km}^{2}\right)$, allowing to conclude that these specific streamflows are different at the $5 \%$ level of significance, based on a hypothesis test conducted for the difference between these two means.

Table 5. Summary of annual average streamflow trend test using MK, MMK, and SS in the Meta River.

\begin{tabular}{|c|c|c|c|c|c|c|c|c|}
\hline No & Station & Mean $\left(\mathrm{m}^{3} / \mathrm{s}\right)$ & Std.Dev $\left(\mathrm{m}^{3} / \mathrm{s}\right)$ & Normal Dist. & MK $Z_{S}$ & MMK $Z_{S}$ & $\mathrm{SS}\left(\mathrm{m}^{3} / \mathrm{s}\right)$ & AC \\
\hline 2 & Cabuyaro & 877.79 & 115.65 & YES & -0.12 & -0.12 & -0.25 & $\mathrm{NO}$ \\
\hline 4 & Puerto Texas & 2252.54 & 260.18 & YES & 0.25 & 0.25 & 0.87 & YES \\
\hline 5 & Santa Maria & 2996.25 & 355.98 & YES & 1.55 & 1.29 & 9.18 & YES \\
\hline 6 & Aguaverde & 3673.22 & 515.11 & YES & 1.69 & 1.69 & 15.19 & $\mathrm{NO}$ \\
\hline 7 & Aceitico & 5126.50 & 829.72 & YES & 1.90 & 1.90 & 21.81 & $\mathrm{NO}$ \\
\hline
\end{tabular}

To summarize these annual results, and based on the information presented in previous tables, Figure 4 provides a schematic representation of trends detected in the annual streamflow of the Meta River.

This study conducted Pettitt's test to evaluate breakpoints in time-series to complement this trend analysis. This nonparametric test is employed to detect a change in the tendency of a time-series. The null hypothesis of "no-change" is tested against the alternative that "a change point exists" [49,50]. These results are shown in Figure 5 for the minimum, average, and maximum annual streamflows at the Meta River, considering a 5\% significance level to identify the specific location of the change points. This figure also includes the SS plot for these streamflow variables. 


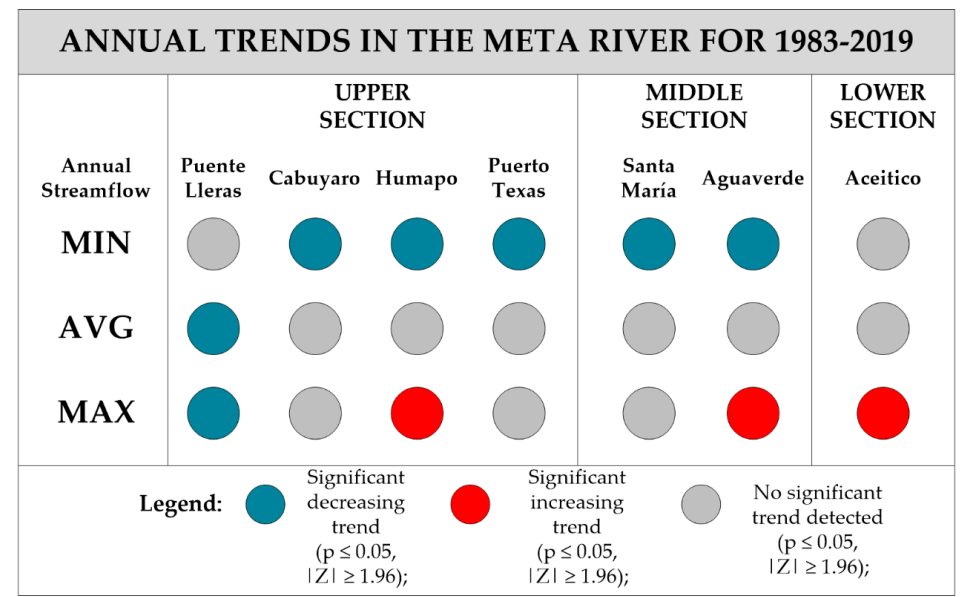

Figure 4. Schematic representation of trends in the Meta River annual streamflow for 1983-2019.

\begin{tabular}{|c|c|c|}
\hline $\begin{array}{l}\text { Anr } \\
\text { Stre }\end{array}$ & $\begin{array}{l}\text { Anr } \\
\text { Stre }\end{array}$ & Streamflov \\
\hline 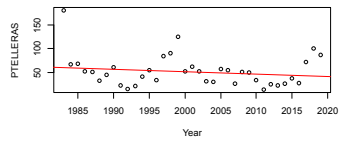 & 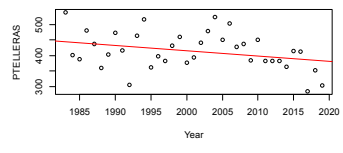 & $\therefore \therefore \cdots$ \\
\hline p-Value: 0.5608 Chang & $p-V_{a}$ & $662 \mathrm{Cha}$ \\
\hline 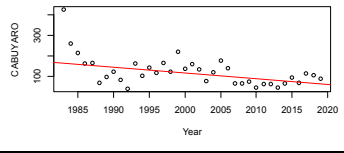 & 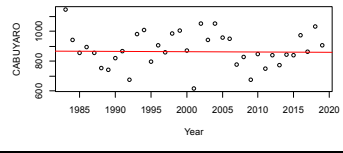 & 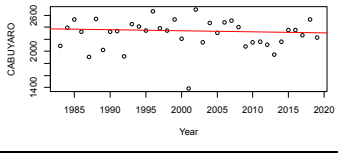 \\
\hline p-Value: 0.0014 Chang & 1e: 0.8959 Change point: N/A & 0 \\
\hline 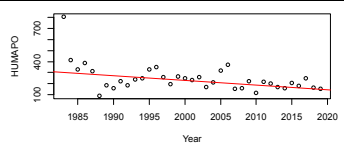 & 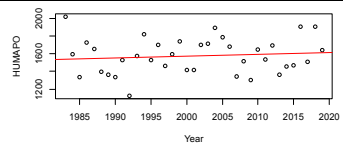 & 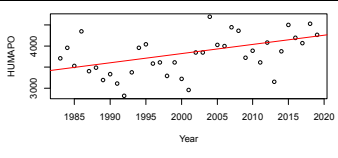 \\
\hline lue: 0.0024 Chang & 0.5738 & $0.0,00$ \\
\hline 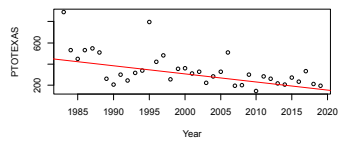 & 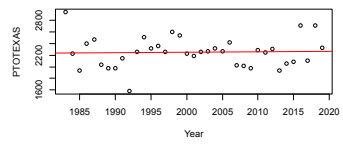 & 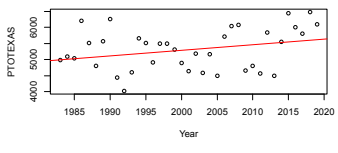 \\
\hline $0.0001 \mathrm{Ch}$ & N/A & 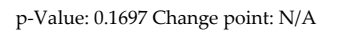 \\
\hline 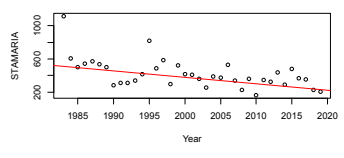 & 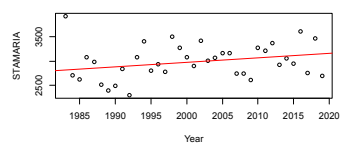 & 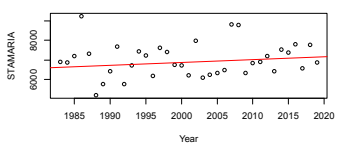 \\
\hline p-Value: 0.0004 Change & p-Value: 0.1954 Chang & int: $\mathrm{N}$ \\
\hline 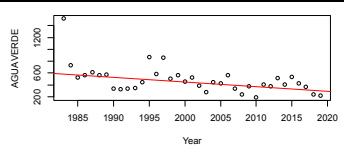 & 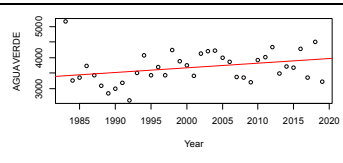 & 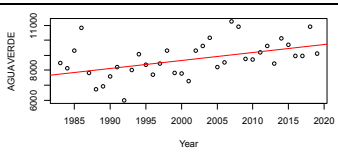 \\
\hline $\mathrm{p}$-Value: 0.0011 Change $\mathrm{p}$ & p-Value: 0.0916 Change point: N/A & -Value: 0.0019 Chan \\
\hline 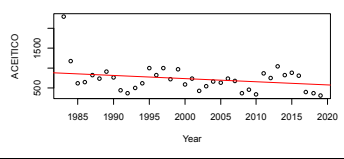 & 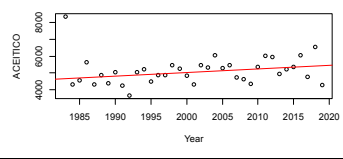 & 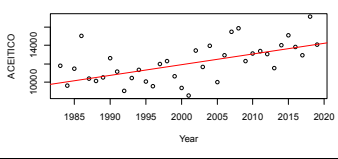 \\
\hline Value: & p-Value: & 1 \\
\hline
\end{tabular}

Figure 5. Pettitt's test results and SS plot for minimum, average, and maximum annual streamflows in the Meta River. 


\section{Discussion}

For the period between June 1983 and July 2019, the initial assessment conducted on the 105 datasets evidenced the relevance of the non-parametric characteristic of the MK test and the SS estimator, as $23 \%$ of these datasets failed the normality test at a $95 \%$ level of confidence. More than a third (38 of 105) of the evaluated datasets presented significant trends at a $95 \%$ level of confidence, with a prevalence of upward (22) slopes.

\subsection{Analysis of Trends Based on Their Spatial Distribution}

From the results in Table 2, the four upstream stations (Puente Lleras, Cabuyaro, Humapo, and Puerto Texas) exhibited significant decreasing trends within the range of $-14 \mathrm{~m}^{3} / \mathrm{s} \cdot$ year to $-3 \mathrm{~m}^{3} / \mathrm{s} \cdot$ year for months with the lowest streamflows (January to March) and at the end of the wet season (September to October). The behavior in these stations is mostly a consequence of variations in the streamflow of three Meta River tributaries: Metica River, Upia River, and Manacacias River.

The stations in the middle and lower parts of the basin (Santa Maria, Aguaverde, and Aceitico) presented significant increasing trends in the months with the highest discharges (April to July), with variations within the range from $27 \mathrm{~m}^{3} / \mathrm{s} \cdot$ year to $87 \mathrm{~m}^{3} / \mathrm{s} \cdot$ year. These changes are attributable to the streamflow changes of the rivers: Cravo Sur, Cusiana, and Casanare; the three of them tributaries discharging in the middle section of the Meta River.

When considering only the twenty-eight significant trends found for the monthly average streamflow, the Sen's slope (SS) values in Table 2 show that Aceitico station presents, between May and July, the steepest slopes of the set of monthly average discharges, followed by Aguaverde for the same period, with both of them exhibiting positive trends.

The results in Table 3, summarizing the trends for annual maximum streamflow, indicate that four stations exhibited significant trends (three upwards, one downwards). The steepest slopes, with Sen's slope values between $53 \mathrm{~m}^{3} / \mathrm{s} \cdot$ year and $115 \mathrm{~m}^{3} / \mathrm{s} \cdot$ year, correspond to the two most downstream stations (Aguaverde and Aceitico), and these values are mostly explained by the trends exhibited during the months with the highest streamflow values (May to July), as discussed in the previous paragraph.

The summarized analysis for annual minimum streamflow shown in Table 4 revealed the existence of significant trends in five gauging stations, with all of them presenting downward trends and SS values between $-3 \mathrm{~m}^{3} / \mathrm{s} \cdot$ year to $-8 \mathrm{~m}^{3} / \mathrm{s} \cdot$ year, this is approximately $2 \%$ of the current average of the annual minimum at this station. The four most upstream gauging stations exhibited significant decreasing trends that can be explained by the similar downward trends found in the dry season months (see Table 2). As for the annual average, the results shown in Table 5 indicate the existence of significant trends only in the Puente Lleras gauging station, decreasing less than $2 \mathrm{~m}^{3} / \mathrm{s} \cdot \mathrm{year}(<1 \%$ of the current mean annual streamflow).

The power spectral density for each one of the seven time-series of daily averages was estimated to identify possible relationships between the behavior of the streamflow time-series and macroclimatic phenomena (such as ENSO). The results indicate only two significant peak signals in these series, at frequencies corresponding almost precisely to 0.5 years and 1.0 years (183.4 and 366.9 days). These frequencies match the unimodal behavior of the annual hydrograph (see Figure 3). As no other significant frequencies are detected, it is possible to rule out the relationship with periodic macroclimatic events. This result is in line with previous studies that analyzed the relationship between precipitation and streamflows in the region of the Orinoco basin with macroclimatic phenomena such as ENSO [51,52]. Their findings also suggest that this system is not affected by this phenomenon's signal, as the correlation values between these parameters and ENSO is approximately zero. It is worth mentioning that this is different from the behavior of some Colombian rivers discharging in the Caribbean sea, as the latter exhibit a significant relationship with strong ENSO events and Pacific Decadal Oscillation [25-27].

Land cover changes may impact infiltration rates and runoff volumes [53]. IDEAM assessed land cover changes in the Meta River Basin, and produced a set of maps for the periods 2000-2002, 2005-2006, 
and 2010-2012, through an adaptation of the CORINE Land Cover methodology to Colombia [54]. As part of the present study, the geoprocessing of these maps indicates that forests and semi-natural areas cover approximately $71 \%$ of this watershed, followed by agriculture $(25 \%)$. The remaining percentage is divided among wetlands $(2 \%)$, water bodies $(1.7 \%)$, and artificial land cover $(0.3 \%)$. During this time-window, land cover variations in the Meta River watershed were less than $1 \%$ for every category, which is consistent with previous research carried out for Colombia [55] and the study conducted by the Food and Agriculture Organization of the United Nations (FAO) [56]. The latter indicates that between 1992 and 2017, the total tree-covered area in this South American country has decreased less than $2 \%$.

Therefore, there is not enough evidence suggesting that land cover changes or macroclimatic phenomena are responsible for the statistically significant trends detected in the time-series assessed in this paper for the Meta River, especially for those that presented significant p-values for the Pettitt's test. With no major hydrotechnical projects in this river, the effect of other hydroclimatic variables and natural variability are possible drivers of these changes.

\subsection{Site-Specific Analysis of Trends}

In general, the four most upstream stations in the main course of the Meta River exhibited mostly downward trends for the streamflow variables evaluated, while only significant upward trends were detected for the three most downstream stations. The results from Table 3, Table 4, and Table 5 allow observing that, for every scenario, at least one station exhibits a significant annual trend at a $95 \%$ level of confidence. Still, none of the seven gauging stations suggests a substantial variation in all three evaluated annual features of the streamflow. The ones that show significant trends twice are Puente Lleras, Humapo, and Aguaverde. The individual results for each gauging station indicate:

- Puente Lleras: The most upstream gauging station is the only station than exhibited significant trends in its annual average streamflow. Additionally, the annual maximum streamflow in this station also presents a downward trend; however, this represents less than $0.6 \%$ of the current average of the annual maximum streamflows in this station.

- Cabuyaro: The results for this gauging station indicate only two statistically significant trends for the monthly averages in February (downward) and April (upward), as well as in the annual minimum streamflow (downward).

- Humapo: This gauging station presented a significant downward trend for the average monthly streamflow for February and upward trends for the middle months of the wet season. As a noteworthy feature, this station, along with Aguaverde, exhibit significant trends that suggest decreasing annual minimum streamflows and increasing annual maximum discharges.

- Puerto Texas: The trend analysis for station indicated significant trends for the average streamflows of three months, two of them in the dry season (downward), and one increasing in the wet season. In terms of its annual features, only the minimum streamflow in this station presents a significant downward trend.

- Santa Maria: This gauging station showed a statistically significant downward trend for the monthly average of February, and upward trends at a 95\% level of confidence for the monthly average streamflow for April, May, June, and November. This behavior does not seem to have an impact on the annual maximum and annual average streamflow, as they do not show significant trends.

- Aguaverde: The results for this station indicate the existence of statistically significant trends at a 95\% level of confidence for the annual maximum (upward) and annual minimum streamflow (downward). The increase is more evident, and it can be explained by the behavior of the average monthly streamflow during the wet season, where most of these months show some of the steepest slopes of the entire set. Additionally, for November, the MMK test detected a significant trend, while the MK did not, evidencing the effects of correlation in trend detection. 
- Aceitico: The most downstream gauging station exhibited increasing annual maximum streamflows, also presenting the steepest slope of the whole set of results. The trend detection through the MMK test differed from the MK test in the monthly averages of June and November. A previous study indicated that the average annual streamflow for the period between 1970 and 2000 displayed a downward trend [57], suggesting a change in the direction of the trend occurring over the last two decades.

It is worth mentioning that a previous study [58] compared field measurements with IDEAM data records, with findings showing differences of around $10 \%$ between these two sources, suggesting that uncertainty related to IDEAM records could be higher than that associated to the magnitude of the trends evaluated in this study.

\section{Conclusions}

This paper characterized, quantified, and validated trends in the monthly average, annual average, annual maximum, and annual minimum streamflows of the Meta River in the basin that is entirely located in Colombia and is one major tributary of the Orinoco River. The study employed the MK and the MKK trend tests and the SS estimator for assessing the streamflow variability in the time-series from seven gauging stations in the main course of the river, for the period between 1983 and 2019 . Some of the main findings of this research are:

- The hydrographs of the seven stations evidenced a unimodal distribution over the year, with peak flows occurring between June and July, and two clearly defined seasons.

- All of the seven streamflow gauging stations under analysis presented statistically significant trends for at least one of their annual variables (minimum, average, maximum). Perhaps the most relevant change is observed in the annual minima, as there are five consecutive stations in the upper and middle section of the river exhibiting significant decreasing trends at a $95 \%$ level of confidence. However, the specific streamflow changes corresponding to this variation are less than $0.2 \mathrm{l} / \mathrm{s} / \mathrm{km}^{2}$, which is well within the range of uncertainty associated with the IDEAM measurement processes. Similarly, the two most downstream stations exhibited significant upward trends for their annual maximum streamflow, corresponding to a change between $0.7 \mathrm{l} / \mathrm{s} / \mathrm{km}^{2}$ and $1.1 \mathrm{l} / \mathrm{s} / \mathrm{km}^{2}$, also within the estimated range of uncertainty.

- The Pettitt's test was conducted for determining breakpoints in the time-series, in order to assess possible sources of change in the streamflow regimes of the Meta River, and the years 2001 and 2006 were found as the most common significant change points. However, power spectral density analysis and land cover change assessments conducted in this research suggest that there is no evidence for accepting the hypothesis that macroclimatic phenomena or anthropic actions on the local scale are the main cause of the trends for these time-series. Therefore, a future research direction is to conduct a multivariate analysis, including additional hydroclimatic parameters for evaluating if they contribute to the observed changes.

The findings of this study are a useful tool for water resources management and sustainable planning in the Meta River Basin, as they help to improve the understanding of how hydrologic variability affects water availability and its impact on human activities that depend on water resources. Based on these findings, one future research direction could be to assess the hydrological variability on a sub-basin scale within the Meta River watershed, including other gauging stations located in the tributaries of this river. This type of assessment would allow identification of probable anthropogenic or natural drivers of change and to evaluate different possible scenarios, with the help of hydrological and mathematical models.

Author Contributions: Conceptualization, G.J.A., and F.A.C.; methodology, G.J.A., and F.A.C.; software, F.A.C., M.A.-C., and A.D.-R.; validation, F.A.C., M.A.-C., and A.D.-R.; formal analysis, G.J.A., F.A.C., M.A.-C., A.D.-R., B.K., and R.S.V.T.; investigation, M.A.-C., and A.D.-R.; writing-original draft preparation, M.A.-C., and A.D.-R.; 
writing-review and editing, G.J.A., F.A.C., B.K. and R.S.V.T.; supervision, F.A.C. All authors have read and agreed to the published version of the manuscript.

Funding: This research received no external funding.

Acknowledgments: The authors would like to thank IDEAM for kindly providing the time-series employed in this paper.

Conflicts of Interest: The authors declare no conflict of interest.

\section{References}

1. Grizzetti, B.; Lanzanova, D.; Liquete, C.; Reynaud, A.; Cardoso, A.C. Assessing water ecosystem services for water resource management. Environ. Sci. Policy 2016, 61, 194-203. [CrossRef]

2. Silva, A.T. Introduction to Nonstationary Analysis and Modeling of Hydrologic Variables. In Fundamentals of Statistical Hydrology; Naghettini, M., Ed.; Springer International Publishing: Cham, Switzerland, 2017; pp. 537-577.

3. Arfan, M.; Lund, J.; Hassan, D.; Saleem, M.; Ahmad, A. Assessment of Spatial and Temporal Flow Variability of the Indus River. Resources 2019, 8, 103. [CrossRef]

4. Ali, R.; Ismael, A.; Heryansyah, A.; Nawaz, N. Long Term Historic Changes in the Flow of Lesser Zab River, Iraq. Hydrology 2019, 6, 22. [CrossRef]

5. Tadese, M.T.; Kumar, L.; Koech, R.; Zemadim, B. Hydro-Climatic Variability: A Characterisation and Trend Study of the Awash River Basin, Ethiopia. Hydrology 2019, 6, 35. [CrossRef]

6. Langat, P.; Kumar, L.; Koech, R. Temporal Variability and Trends of Rainfall and Streamflow in Tana River Basin, Kenya. Sustainability 2017, 9, 1963. [CrossRef]

7. Yilmaz, A.G.; Perera, B.J.C. Spatiotemporal Trend Analysis of Extreme Rainfall Events in Victoria, Australia. Water Resour. Manag. 2015, 29, 4465-4480. [CrossRef]

8. Wdowikowski, M.; Kaźmierczak, B.; Ledvinka, O. Maximum daily rainfall analysis at selected meteorological stations in the upper Lusatian Neisse River basin. Meteorol. Hydrol. Water Manag. 2016, 4, 53-63. [CrossRef]

9. Pellicciotti, F.; Burlando, P.; Van Vliet, K. Recent trends in precipitation and streamflow in the Aconcagua River Basin, central Chile. In IAHS Assembly; IAHS Publ.: Foz do Iguaçu, Brazil, 2007; pp. 1-22.

10. Su, L.; Miao, C.; Kong, D.; Duan, Q.; Lei, X.; Hou, Q.; Li, H. Long-term trends in global river flow and the causal relationships between river flow and ocean signals. J. Hydrol. 2018, 563, 818-833. [CrossRef]

11. Feng, J.; Li, D.; Wang, T.; Liu, Q.; Deng, L.; Zhao, L. Acceleration of the Extreme Sea Level Rise Along the Chinese Coast. Earth Space Sci. 2019, 6, 1942-1956. [CrossRef]

12. Teegavarapu, R.S.V. Methods for Analysis of Trends and Changes in Hydroclimatological Time-Series. In Trends and Changes in Hydroclimatic Variables; Teegavarapu, R.S.V., Ed.; Elsevier: Amsterdam, The Netherlands, 2019; pp. 1-89.

13. Şener, Ş.; Şener, E.; Davraz, A. Evaluation of water quality using water quality index (WQI) method and GIS in Aksu River (SW-Turkey). Sci. Total Environ. 2017, 584-585, 131-144. [CrossRef]

14. Ndehedehe, C.E.; Ferreira, V.G. Assessing land water storage dynamics over South America. J. Hydrol. 2020, 580, 124339. [CrossRef]

15. Vega-Jácome, F.; Lavado-Casimiro, W.S.; Felipe-Obando, O.G. Assessing hydrological changes in a regulated river system over the last 90 years in Rimac Basin (Peru). Theor. Appl. Climatol. 2018, 132, 347-362. [CrossRef]

16. Morán-Tejeda, E.; Bazo, J.; López-Moreno, J.I.; Aguilar, E.; Azorín-Molina, C.; Sanchez-Lorenzo, A.; Martínez, R.; Nieto, J.J.; Mejía, R.; Martín-Hernández, N.; et al. Climate trends and variability in Ecuador (1966-2011). Int. J. Climatol. 2016, 36, 3839-3855. [CrossRef]

17. Seoane, R.; López, P. Assessing the effects of climate change on the hydrological regime of the Limay River basin. GeoJournal 2007, 70, 251-256. [CrossRef]

18. Vich, A.I.J.; López, P.M.; Schumacher, M.C. Trend detection in the water regime of the main rivers of the Province of Mendoza, Argentina. GeoJournal 2007, 70, 233-243. [CrossRef]

19. De Santos, V.O.; Nishiyama, L. Tendências Hidrológicas no Alto Curso da Bacia Hidrográfica do Rio Uberaba, em Minas Gerais. Caminhos Geogr. 2016, 17, 196-212. [CrossRef]

20. De Alcântara, L.R.P.; de Costa, I.R.A.; de Barros, V.H.O.; Santos Neto, S.M.; Coutinho, A.P.; Antonino, A.C.D. Análise de tendência para dados pluviométricos no município de Toritama-PE. J. Environ. Anal. Prog. 2019, 4, 130. [CrossRef] 
21. De Quadros, L.E.; de Mello, E.L.; Gomes, B.M.; Araujo, F.C. Rainfall trends for the State of Paraná: Present and future climate. Ambient. Agua Interdiscip. J. Appl. Sci. 2019, 14, 1. [CrossRef]

22. Rodrigues, A.L.M.; Reis, G.B.; dos Santos, M.T.; da Silva, D.D.; dos Santos, V.J.; de Siqueira Castro, J.; Calijuri, M.L. Influence of land use and land cover's change on the hydrological regime at a Brazilian southeast urbanized watershed. Environ. Earth Sci. 2019, 78, 595. [CrossRef]

23. De Santos, V.O.; de Naves, J.G.P. Low flow diagnosis on upper course of Uberaba river basin. Ambiência 2016, 12, 859-868. [CrossRef]

24. Trindade, A.L.C.; de Almeida, K.C.B.; Barbosa, P.E.; Oliveira, S.M.A.C. Tendências temporais e espaciais da qualidade das águas superficiais da sub-bacia do Rio das Velhas, estado de Minas Gerais. Eng. Sanit. Ambient. 2016, 22, 13-24. [CrossRef]

25. Restrepo, J.C.; Ortíz, J.C.; Maza, M.; Otero, L.; Alvarado, M.; Aguirre, J. Estimating fluvial discharge in the Caribbean seaboard of Colombia: Magnitude, variability and extreme events. Coast. Eng. Proc. 2012, 1, 44. [CrossRef]

26. Restrepo, J.C.; Ortíz, J.C.; Pierini, J.; Schrottke, K.; Maza, M.; Otero, L.; Aguirre, J. Freshwater discharge into the Caribbean Sea from the rivers of Northwestern South America (Colombia): Magnitude, variability and recent changes. J. Hydrol. 2014, 509, 266-281. [CrossRef]

27. Restrepo, J.D.; Escobar, H.A. Sediment load trends in the Magdalena River basin (1980-2010): Anthropogenic and climate-induced causes. Geomorphology 2018, 302, 76-91. [CrossRef]

28. Restrepo, J.D.; Escobar, R.; Tosic, M. Fluvial fluxes from the Magdalena River into Cartagena Bay, Caribbean Colombia: Trends, future scenarios, and connections with upstream human impacts. Geomorphology 2018, 302, 92-105. [CrossRef]

29. Ávila, Á.; Guerrero, F.; Escobar, Y.; Justino, F. Recent Precipitation Trends and Floods in the Colombian Andes. Water 2019, 11, 379. [CrossRef]

30. Puertas-Orozco, O.L.; Carvajal-Escobar, Y.; Quintero-Angel, M. Estudio de tendencias de la precipitación mensual en la cuenca alta-media del río Cauca, Colombia. DYNA 2011, 78, 112-120.

31. Carmona, A.M.; Poveda, G. Detection of long-term trends in monthly hydro-climatic series of Colombia through Empirical Mode Decomposition. Clim. Change 2014, 123, 301-313. [CrossRef]

32. Ardila Luna, D.C. El río Meta y los proyectos para la integración de los Llanos Orientales colombianos, desde la Colonia hasta el siglo XXI. Anu. Hist. Reg. Front. 2016, 21, 265-283.

33. Ministerio de Transporte Plan Maestro Fluvial de Colombia 2015. 2015; $108 . \quad$ Available online: $\quad$ https://www.google.com.hk/url?sa=t\&rct=j\&q=\&esrc=s\&source=web\&cd=1\&ved= 2ahUKEwi7x8zh4MHpAhVNCqYKHQb1C6EQFjAAegQIAxAB\&url=https\%3A\%2F\%2Fwww. mintransporte.gov.co\%2Fdescargar.php\%3FidFile\%3D13276\&usg=AOvVaw2Eky0KTUsR1_G0JSnb7I_1 (accessed on 15 May 2020).

34. Liu, L.; Wen, Y.; Liang, Y.; Zhang, F.; Yang, T. Extreme weather impacts on inland waterways transport of Yangtze River. Atmosphere (Basel) 2019, 10, 133. [CrossRef]

35. Actualización de los Estudios y Diseños para la Navegabilidad del río Meta entre Cabuyaro (K804) y Puerto Carreño (K0); Universidad del Norte: Barranquilla, Colombia, 2013.

36. Acuña, G.J.; Ávila, H.; Canales, F.A. River Model Calibration Based on Design of Experiments Theory. A Case Study: Meta River, Colombia. Water 2019, 11, 1382. [CrossRef]

37. Warne, A.G.; Meade, R.H.; White, W.A.; Guevara, E.H.; Gibeaut, J.; Smyth, R.C.; Aslan, A.; Tremblay, T. Regional controls on geomorphology, hydrology, and ecosystem integrity in the Orinoco Delta, Venezuela. Geomorphology 2002, 44, 273-307. [CrossRef]

38. IDEAM. Estudio Nacional del Agua; Instituto de Hidrología, Meteorología y Estudios Ambientales: Bogotá DC, Colombia, 2010.

39. IDEAM. Consulta y Descarga de Datos Hidrometeorológicos. Available online: http://dhime.ideam.gov.co/ atencionciudadano/ (accessed on 10 October 2019).

40. Umar, D.A.; Ramli, M.F.; Aris, A.Z.; Jamil, N.R.; Aderemi, A.A. Evidence of climate variability from rainfall and temperature fluctuations in semi-arid region of the tropics. Atmos. Res. 2019, 224, 52-64. [CrossRef]

41. Salman, S.A.; Shahid, S.; Ismail, T.; Chung, E.-S.; Al-Abadi, A.M. Long-term trends in daily temperature extremes in Iraq. Atmos. Res. 2017, 198, 97-107. [CrossRef]

42. Hamed, K.H.; Rao, A.R. A modified Mann-Kendall trend test for autocorrelated data. J. Hydrol. 1998, 204, 182-196. [CrossRef] 
43. Kibria, K.N.; Ahiablame, L.; Hay, C.; Djira, G. Streamflow trends and responses to climate variability and land cover change in South Dakota. Hydrology 2016, 3, 2. [CrossRef]

44. Yue, S.; Pilon, P.; Phinney, B.; Cavadias, G. The influence of autocorrelation on the ability to detect trend in hydrological series. Hydrol. Process. 2002, 16, 1807-1829. [CrossRef]

45. Winslow, L.A.; Read, J.S.; Hansen, G.J.A.; Hanson, P.C. Small lakes show muted climate change signal in deepwater temperatures. Geophys. Res. Lett. 2015, 42, 355-361. [CrossRef]

46. Mohd Razali, N.; Bee Wah, Y. Power comparisons of Shapiro-Wilk, Kolmogorov-Smirnov, Lilliefors and Anderson-Darling tests. J. Stat. Model. Anal. 2011, 2, 21-33.

47. Lozano Blanco, L.J.; Meseguer Zapata, V.F.; De Juan García, D. Statistical analysis of laboratory results of Zn wastes leaching. Hydrometallurgy 1999, 54, 41-48. [CrossRef]

48. Ahmad, I.; Tang, D.; Wang, T.; Wang, M.; Wagan, B. Precipitation trends over time using Mann-Kendall and spearman's Rho tests in swat river basin, Pakistan. Adv. Meteorol. 2015, 2015, 15. [CrossRef]

49. Pohlert, T. Package "Trend": Non-Parametric Trend Tests and Change-Point Detection. Available online: https://cran.r-project.org/package=trend (accessed on 3 March 2020).

50. Xu, S.; Qin, M.; Ding, S.; Zhao, Q.; Liu, H.; Li, C.; Yang, X.; Li, Y.; Yang, J.; Ji, X. The impacts of climate variation and land use changes on streamflow in the Yihe River, China. Water (Switzerland) 2019, 11, 887. [CrossRef]

51. Guarín Giraldo, G.W.; Poveda, G. Variabilidad espacial y temporal del almacenamiento de agua en el suelo en Colombia. Rev. Acad. Colomb. Ciencias Exactas Físicas Nat. 2013, 37, 89-113.

52. Estudio Nacional del Agua 2018; IDEAM: Bogota, Colombia, 2019.

53. Guse, B.; Kail, J.; Radinger, J.; Schröder, M.; Kiesel, J.; Hering, D.; Wolter, C.; Fohrer, N. Eco-hydrologic model cascades: Simulating land use and climate change impacts on hydrology, hydraulics and habitats for fish and macroinvertebrates. Sci. Total Environ. 2015, 533, 542-556. [CrossRef]

54. IDEAM. Leyenda Nacional de Coberturas de la Tierra. Metodología CORINE Land Cover Adaptada para Colombia Escala 1:100.000; Instituto de Hidrología, Meteorología y Estudios Ambientales: Bogota, DC, Colombia, 2010.

55. Armenteras, D.; González, T.; Meza, M.; Ramírez-Delgado, J.P.; Cabrera, E.; Galindo, G.; Yepes, A. Causas de Degradación Forestal en Colombia: Una Primera Aproximación; Universidad Nacional de Colombia Sede Bogotá, Instituto de Hidrología, Meteorología y Estudios Ambientales de Colombia-IDEAM, Programa ONU-REDD: Bogota, DC, Colombia, 2018.

56. Food and Agriculture Organization of the United Nations FAOSTAT. Available online: http://www.fao.org/ faostat/en/\#data/LC/visualize (accessed on 20 April 2020).

57. IDEAM. Informe Anual Sobre el Estado del Medio Ambiente y los Recursos Naturales Renovables de Colombia; Imprenta Nacional: Bogota, Colombia, 2004.

58. Torres Pungo, K.; Rivera, H.G.; Rivera, M.; Fuentes Bacca, J.B.; León Alvarez, M.A. Identificación de la incertidumbre en el proceso estocástico de caudales medios en el río Fonce (San Gil-Santander). Av. Investig. Ing. 2015, 12, 1. [CrossRef]

(C) 2020 by the authors. Licensee MDPI, Basel, Switzerland. This article is an open access article distributed under the terms and conditions of the Creative Commons Attribution (CC BY) license (http://creativecommons.org/licenses/by/4.0/). 